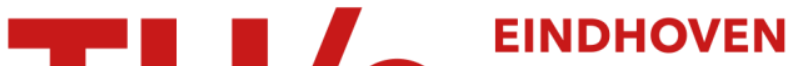 \\ UNIVERSITY OF \\ TECHNOLOGY
}

\section{Crystal structure and semiconductivity of tetraethylammonium bis(isotrithionedithiolato)nickelate(III)}

\section{Citation for published version (APA):}

Groeneveld, L. R., Schuller, B., Kramer, G. J., Haasnoot, J. G., \& Reedijk, J. A. (1986). Crystal structure and semiconductivity of tetraethylammonium bis(isotrithionedithiolato)nickelate(III). Recueil des Travaux Chimiques des Pays-Bas, 105(11), 507-509.

\section{Document status and date:}

Published: 01/01/1986

\section{Document Version:}

Publisher's PDF, also known as Version of Record (includes final page, issue and volume numbers)

\section{Please check the document version of this publication:}

- A submitted manuscript is the version of the article upon submission and before peer-review. There can be important differences between the submitted version and the official published version of record. People interested in the research are advised to contact the author for the final version of the publication, or visit the $\mathrm{DOI}$ to the publisher's website.

- The final author version and the galley proof are versions of the publication after peer review.

- The final published version features the final layout of the paper including the volume, issue and page numbers.

Link to publication

\section{General rights}

Copyright and moral rights for the publications made accessible in the public portal are retained by the authors and/or other copyright owners and it is a condition of accessing publications that users recognise and abide by the legal requirements associated with these rights.

- Users may download and print one copy of any publication from the public portal for the purpose of private study or research.

- You may not further distribute the material or use it for any profit-making activity or commercial gain

- You may freely distribute the URL identifying the publication in the public portal.

If the publication is distributed under the terms of Article 25fa of the Dutch Copyright Act, indicated by the "Taverne" license above, please follow below link for the End User Agreement:

www.tue.nl/taverne

Take down policy

If you believe that this document breaches copyright please contact us at:

openaccess@tue.nl

providing details and we will investigate your claim. 
CRYSTAL STRUCTURE AND SEMICONDUCTIVITY OF TETRAETHYLAMMONIUM BIS(ISOTRITHIONEDITHIOLATO) NICKELATE (III).

L.R. Groeneveld* B. Schuller ${ }^{*}$, G.J. Kramert, J.G. Haasnoot ${ }^{*}$ and J. Reedijk*

*Department of Chemistry, Gortaeus Laboratories, State University Leiden, P.O. Box 9502, 2300 RA Leiden, The NetherLands

tKamerlingh onnes Laboratories, State University Leiden, P.O. Box 9506, 2300 RA Leiden, The Netherlands.

(Received August 18th, 1986)

Abstract. The synthesis and crystal structure of $\left(\left(\mathrm{C}_{2} \mathrm{H}_{5}\right)_{4} \mathrm{~N}\right)\left\{\mathrm{Ni}\left(\mathrm{C}_{3} \mathrm{~S}_{5}\right)_{2}\right\}$ is described. Space group $P 21 / n$ with $a=7.333(1) \AA, b=25.734(3) \AA, \quad c=12.798(4) \AA, \quad \beta=104.95(2)^{\circ}$ and $Z=4$. The structure consists of a one-dimensional zig-zag chain with alternating Ni-Ni distances of $4.163 \AA$ and $4.243 \AA$, respectively. The temperature dependence of the conductivity shows an unusual behaviour. The relationship $\ln (\sigma) \infty \mathrm{T}^{-1 / 2}$ is followed instead of the common semiconductor "behaviour of $\ln (\sigma) \infty 1 / T$. The unexpectedly high value of the conductivity is related to the size of the counter cation in the crystal lattice.

Considerable effort has been devoted to the preparation and study of conducting molecular solids and, in particular, the development of "molecular metals" and superconductors ${ }^{1-3}$. The crystals of partially oxidized 1,2-dithiolene complexes have the conduction pathway based on the ligand-centered $\pi$-system (predominantly sulfur orbitals), while partially occupied $M-\mathrm{d}_{\mathrm{z}} 2$ electron energy band is responsible for the high conductivity of the inorganic one-dimensional metals containing tetracyanoplatinate and bis(oxalato)platinate anions ${ }^{4}$.

Transition metal ions coordinated by the organic ligand dmit (isotrithionedithiolato), provide a suitable acceptor molecule, which can be made to form highly anisotropic (low-dimensional) metals or semiconductors and also an isotropic superconductor $^{3}$. In the literature examples of these systems are found exhibiting both 1 - and 2-dimensional electronic behaviour ${ }^{5-6}$. We now report the synthesis of a semiconductor, with an unusual conducting behaviour, and the characterization by spectrosco- pic and X-ray diffraction determination of the structure. The dianionic starting product $\left(\left(\mathrm{C}_{2} \mathrm{H}_{5}\right)_{4} \mathrm{~N}\right)_{2}\left\{\mathrm{Ni}(\mathrm{dmit})_{2}\right\}$, has been prepared following a synthetic method described in the literature 5,7 using $\left(\mathrm{C}_{2} \mathrm{H}_{5}\right)_{4} \mathrm{NBr}$ instead of $\left(\mathrm{C}_{4} \mathrm{Hg}_{9}\right)_{4} \mathrm{NBr}$. Reaction of sodium or potassium with $\mathrm{CS}_{2}$ yields the dmit ${ }^{2-}$ anion, which is stabilized and isolated as the zinc salt. Subsequent reaction with benzoylchloride and sodium methoxide regenerates the dmit $^{2-}$ ligand; this is followed by the addition of the appropriate metal salt. The $\left(\mathrm{Et}_{4} \mathrm{~N}\right)\left\{\mathrm{Ni}(\mathrm{dmit})_{2}\right\}$ coordination compound has been prepared following different pathways: (i) oxidation of $\left(\mathrm{Et}_{4} \mathrm{~N}\right)_{2}\left\{\mathrm{Ni}(\mathrm{dmit})_{2}\right\}$ by iodine $\left(\mathrm{I}_{2}\right)$; (ii) auto-oxidation of $\left(\mathrm{Et}_{4} \mathrm{~N}\right)_{2}\left\{\mathrm{Ni}(\mathrm{dmit})_{2}\right\}$ using the methods, under identical experimental conditions, described first by Steimecke and co-workers ${ }^{7}$ for the synthesis of $\left(\mathrm{Bu}_{4} \mathrm{~N}\right)\left\{\mathrm{Ni}(\mathrm{dmit})_{2}\right\}$. The needle-shaped crystals, synthesized according to $(i)$, were used for the chemical analysis, X-ray diffraction determination and the conductivity measurement. Elemental analy- 
sis for $\left(\left(\mathrm{C}_{2} \mathrm{H}_{5}\right)_{4} \mathrm{~N}\right)\left\{\mathrm{Ni}\left(\mathrm{C}_{3} \mathrm{~S}_{5}\right)_{2}\right\}$ : calcd. Ni, 10.09; $\mathrm{C}, 28.91 ; \mathrm{H}, 3.47 ; \mathrm{N} ; 2.41 ; \mathrm{S}, 55.12$; found $\mathrm{Ni}$, $10.02 ; \mathrm{C}, 28.57 ; \mathrm{H}, 3.41 ; \mathrm{N}, 2.19 ; \mathrm{S}, 55.33$. The downfield shifts of the $C=C$ vibrations upon oxidation, (1434 $\mathrm{cm}^{-1}$ for $\mathrm{Ni}$ (II) and $1350 \mathrm{~cm}^{-1}$ for $\mathrm{Ni}(\mathrm{III}))$ is in agreement with those found in the literature for $\left.\left(\left(\mathrm{C}_{4} \mathrm{H}_{9}\right)_{4} \mathrm{~N}\right)_{2}\right)\left\{\mathrm{Ni}(\mathrm{dmit})_{2}\right\}^{7}$.

The crystal structure of $\left(E t_{4} \mathrm{~N}\right)\left\{\mathrm{Ni}(\mathrm{dmit})_{2}\right\}$ was determined to understand the unusual conductivity. Especially information about the stacking of the

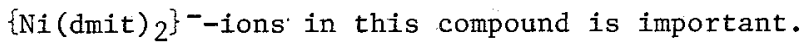
The Ni(III) compound crystallizes in the space group $\mathrm{P} 21 / \mathrm{n}$ with parameters $a=7.333(1) \AA, b=$ 25.734(3) $\AA, c=12.798(4) \AA, \beta=104.95(2)^{\circ}, Z=4$ and mol.wt. $=581.6$. The structure was solved from the Patterson function followed by the use of the program AUTOFOUR ${ }^{8}$ and least-squares refinement. Resulting final $R\left(R_{W}\right)$ values are $4.49(5.36)$ for 1474 significant reflections. The structure contains

$\mathrm{S}$ (5)

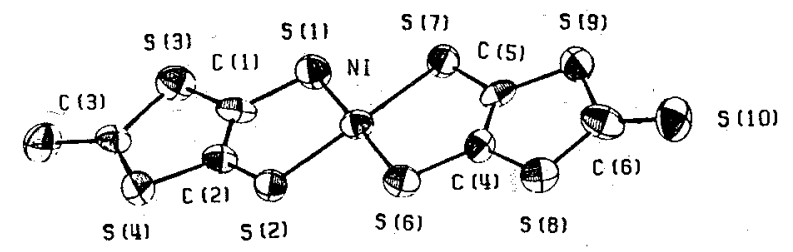

Figure 1. Ortep drawing of the $\left[\mathrm{Ni}(I I I)\left(C_{3} S_{5}\right)_{2}\right]^{-}$ ion with atomic numbering

quasi-planar $\left\{\mathrm{Ni}(\mathrm{dmit})_{2}\right\}^{-}$-ions, face-to-face stacked along the a-axis with alternating $\mathrm{Ni}-\mathrm{Ni}$ distances of $4.163 \AA$ and $4.243 \AA$. The planes containing $\mathrm{Ni}, \mathrm{S} 1-\mathrm{S} 5, \mathrm{C} 1-\mathrm{C} 3$ and $\mathrm{Ni}, \mathrm{S} 7-\mathrm{S} 10, \mathrm{C} 5-\mathrm{C} 6$, respectively, have an inclination of $7.2^{\circ}$. The average value of the $\mathrm{Ni}-\mathrm{S}$ bond distances is $2.157 \AA$ (Table $1)$, which clearly shows that the redox process within the nickeldithiolene complex has taken Table 1. Bond lengths ( $A$ ) and angles $\left({ }^{O}\right)$ within the $\left\{\mathrm{Ni}\left(\mathrm{C}_{3} \mathrm{~S}_{5}\right)_{2}\right\}^{--i o n}$, including cell parameter errors.

$\begin{array}{llll}\text { Ni-S1 } & 2.151(4) & \text { Ni-S1-C1 } & 102.0(4) \\ \text { Ni-S2 } & 2.158(4) & \text { Ni-S2-C2 } & 101.6(4) \\ \text { Ni-S6 } & 2.159(4) & \text { Ni-S6-C4 } & 100.6(5) \\ \text { Ni-S7 } & 2.163(4) & \text { Ni-S7-C5 } & 102.4(5) \\ & & & \\ \text { S1-C1 } & 1.74(1) & \text { S1-C1-C2 } & 120(1) \\ \text { S2-C2 } & 1.69(1) & \text { S1-C1-S3 } & 122.4(7) \\ \text { S3-C1 } & 1.73(1) & \text { C2-C1-S3 } & 118(1) \\ \text { S3-C3 } & 1.77(1) & \text { S2-C2-S4 } & 121.9(7) \\ \text { S4-C2 } & 1.76(1) & \text { S2-C2-C1 } & 123(1) \\ \text { S4-C3 } & 1.72(1) & \text { C1-C2-S4 } & 115(1) \\ \text { S5-C3 } & 1.61(1) & \text { C1-S3-C3 } & 97.7(6) \\ \text { S6-C4 } & 1.73(1) & \text { C2-S4-C3 } & 99.2(6)\end{array}$

$\begin{array}{llll}\text { S7-C5 } & 1.71(1) & \text { S3-C3-S4 } & 110.9(7) \\ \text { S8-C4 } & 1.76(1) & \text { S3-C3-S5 } & 123.2(7) \\ \text { S8-C6 } & 1.73(1) & \text { S4-C3-S5 } & 125.9(8) \\ \text { S9-C5 } & 1.73(1) & \text { S6-C4-C5 } & 123.1(9) \\ \text { S9-C6 } & 1.75(1) & \text { S6-C4-S8 } & 120.5(7) \\ \text { S10-C6 } & 1.64(1) & \text { C5-C4-S8 } & 116.4(9) \\ \text { C1-C2 } & 1.34(1) & \text { S7-C5-S9 } & 124.7(7) \\ \text { C4-C5 } & 1.36(1) & \text { S7-C5-C4 } & 120(1) \\ \text { S1-Ni-S2 } & 93.3(1) & \text { C4-C5-S9 } & 115.2(9) \\ \text { S1-Ni-S7 } & 87.1(1) & \text { C4-S8-C6 } & 97.9(6) \\ \text { S2-Ni-S6 } & 86.0(1) & \text { C5-S9-C6 } & 99.2(6) \\ \text { S6-Ni-S7 } & 93.8(2) & \text { S8-C6-S9 } & 111.1(7) \\ & & \text { S8-C6-S10 } & 124.6(8) \\ & & \text { S9-C6-S10 } & 123.9(8)\end{array}$

place at the central nickel atom (for $\mathrm{Ni}$ (II) the average value of the $\mathrm{Ni}-\mathrm{S}$ bond distances is $2.21 \AA$ ) Short intermolecular contacts between the $\{\mathrm{Ni}$ (dmit) $\}\}^{-}$-ions within the chain are expected give a considerable overlap of the valence orbita and could therefore give rise the observed conduc tivity behaviour (Table 2, Figure 2). It appears that in this compound the chains are well separate since the smallest interchain $S-S$ contact is of th order of $3.8 \AA$, which is larger than the correspond. ing Van der Waals radius ( $3.70 \AA)$. The face-to-face distances along the a-axis are approximately 3.5 and $3.7 \AA$. These distances are comparable with the face-to-face distances found in the compound $\left(\mathrm{Et}_{4} \mathrm{~N}\right)_{0.5}\left\{\mathrm{Ni}(\mathrm{dmit})_{2}\right\}$ which are respectively 3.437 and $3.759 \AA^{6}$. Calculations of the intermolecular overlap integrals (S) of $\left(\mathrm{Et}_{4} \mathrm{~N}\right){ }_{0.5}\left\{\mathrm{Ni}(\mathrm{dmit})_{2}\right\}$, in dicated that the overlap integrals along the faceto-face stacking are much larger than the interstack overlap integrals which is consistent with the highest value of $\sigma$ along that direction.
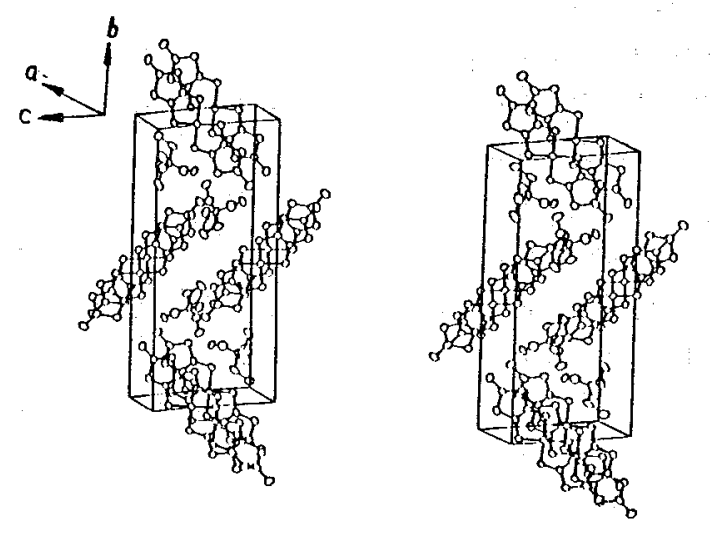

Figure 2. Stereoscopic drowing of the unit cell of (Et $\left.4^{N}\right)$ [Ni(dmit) 2$]$ with stacking along the a-axis. 
Table 2. Some relevant distances within the chain in 8

\begin{tabular}{|c|c|c|c|}
\hline $\mathrm{Ni}(1)$ & $-\mathrm{Ni}(2)$ & 4.163 & \\
\hline $\mathrm{Ni}(1)$ & $-\mathrm{Ni}(3)$ & 4.243 & \\
\hline S8(1) & $\mathrm{S} 4(2)$ & 3.660 & symmetry \\
\hline $54(1)$ & $-\quad s 8(2)$ & 3.660 & operations \\
\hline $\mathrm{Ni}(1)$ & $-\quad s 2(3)$ & 3.506 & (1) $x, y, z$ \\
\hline $\mathrm{S} 2(1)$ & $-\mathrm{Ni}(3)$ & 3.506 & (2) $1-x,-y, 1-z$ \\
\hline S5(1) & $58(3)$ & 3.711 & (3) $-x,-y, 1-z$ \\
\hline $\mathrm{s} 8(1)$ & $-\quad S 5(3)$ & 3.711 & \\
\hline
\end{tabular}

The room temperature conductivity, two-probe technique, of the $\mathrm{Ni}$ (III) is $4 \times 10^{-5}(\Omega \mathrm{cm})^{-1}$ (for $\left.\left(\left(\mathrm{C}_{4} \mathrm{H}_{9}\right)_{4} \mathrm{~N}\right)_{1}\left[\mathrm{Ni}(\mathrm{dmit})_{2}\right] \sigma \approx 3 \times 10^{-8}\right)$ and in preliminary experiments we find that $\sigma_{11}: \sigma_{1}$ exceeds 100. The "activation" energy is $0.25 \mathrm{ev}^{10}$ when analyzed as $1 n \sigma \infty \mathrm{T}^{-1}$ over a small temperature range around room temperature. However, the temperature dependence of the conductivity differs markedly from the usual semiconductor behaviour. The $\ln (\sigma) \infty \mathrm{T}^{-1 / 2}$ law holds over seven decades in the conductivity. Such a behaviour in onedimensional compounds can be attributed to a potential disorder induced on the conducting chain by randomness in the donor system ${ }^{11}$. The room temperature $\mathrm{X}$-ray study and crystal structure indicate that both donors and acceptors form a regular array without any static disorder. Therefore, the application of the above theory seems inadequate ${ }^{10}$. More details about the conductivity measurement and the explanation of the data can be found in the literature ${ }^{10}$.

Further work in this area is directed to explanation of the conducting behaviour of this compound versus the structure and the synthesis of related coordination compounds with different metals and/or cations. This research is sponsored by the Leiden Materials Science Centre (Werkgroep Fundamentee1 Materialenonderzoek).

1. J.T. Devreese, R.P. Evrard and V.E. van Doren, "Highly Conducting One-Dimensional Solids"; Plenum Press: New York (1979)

2. J.S. MizZer, "Extended Linear Chain Compounds"; Plenum Press: New York, Vol. 1,2 (1982); Vol. 3 (1983)

3. M. Bousseau, L. Valade, J-P. Legros,

P. Cassoux, M. Garbauskas and L.V. Interrante, J. Am. Chem. Soc. 108, 1908 (1986) and references therein
4. I.V. Interrante and R.P. Messmer, Chem. Phys. Lett. 26, 225 (1974); A. Kobayashi, Y. Sasaki, H. Kobayashi, A.E. UnderhizZ and M.M. Ahmad, J. Chem. Soc. Chem. Commun. 390 (1982)

5. L. Valade, J-P. Legros, M. Bousseau, P. Cassoux, M. Garbauskas and L.V. Interrante, J. Chem. Soc. Dalton Trans 783 (1985)

6. R. Kato, T. Mori, A. Kobayashi, Y. Sasaki and H. Kobayashi, Chem. Letters 1 (1984)

7. G. Steimecke, H.J. Sieler, R. Kirmse and E. Hoyer, Phosphorus and Sulfur 7, 49 (1979)

8. A.J. Kinneging and R.A.G. de Graaff, J. App1. Cryst. 17, 364 (1984)

9. 0. Lindquist, L. Andersen, J. Siezer, G. Steimecke and E. Hoyer, Acta Chem. Scand. 855 (1982)

10. G.J. Kramer, L.R. Groeneveld, J.L. Joppe, H.B. Brom, L.J. de Jongh and J. Reedijk, Synthetic Metals, accepted for publication

11. A.N. Bloch, R.B. Weisman and C.M. Varma, Phys. Rev. Lett. 753 (1972). 